\title{
Molecular detection of Leishmania spp in Lutzomyia longipalpis in the city of Lavras, Minas Gerais, Brazil
}

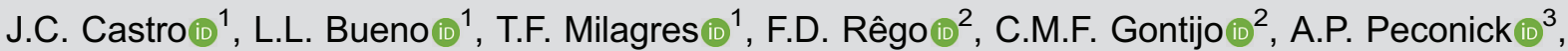 \\ A.J. Andrade (ii) $^{4}$, T.A. Barçante (i) $^{5}$, and J.M.P. Barçante (i) $^{5}$ \\ ${ }^{1}$ Programa de Pós Graduação em Parasitologia, Departamento de Parasitologia, Universidade Federal de Minas Gerais, \\ Belo Horizonte, MG, Brasil \\ ${ }^{2}$ Grupo de Estudo em Leishmanioses, FIOCRUZ, Belo Horizonte, MG, Brasil \\ ${ }^{3}$ Programa de Pós Graduação em Ciências Veterinárias, Departamento de Medicina Veterinária, Universidade Federal de Lavras, \\ Lavras, MG, Brasil \\ ${ }^{4}$ Departamento de Patologia Básica, Universidade Federal do Paraná, Curitiba, PR, Brasil \\ ${ }^{5}$ Programa de Pós Graduação em Ciências da Saúde, Departamento de Ciências da Saúde, Universidade Federal de Lavras, \\ Lavras, MG, Brasil
}

\begin{abstract}
Leishmaniasis is a neglected disease that affects a large part of the world population. Knowing the sand fly fauna of a region is of fundamental importance for guiding health surveillance actions related to the prevention and control of leishmaniasis. A total of 86 specimens of sand flies (60 females and 26 males) were collected. Using the classification proposed by Galati (2003), the following species were identified: Lutzomyia longipalpis (Lutz \& Neiva, 1912), Migonemyia migonei (França, 1920), Evandromyia cortelezzi (Brethes, 1923), Ev. sallesi (Galvão \& Coutinho, 1939), Nyssomyia whitmani (Atunes \& Coutinho, 1939), Psathyromyia lutziana (Costa Lima, 1932), Ev. lenti (Mangabeira, 1938), Brumptomyia sp. (França and Parrot, 1921), and Pressatia sp. (Mangabeira, 1942). Using PCR with internal transcribed spacer target to identify infected sand flies, five Lu. longipalpis females were infected with Leishmania spp. Despite the small number of specimens collected, considerable species diversity was found in the study area.
\end{abstract}

Key words: Leishmaniasis; Sand fly; Epidemiology

\section{Introduction}

Leishmaniasis is a group of diseases caused by protozoa within the genus Leishmania that are transmitted through the bites of female sand flies (1). The transmission pattern of Leishmania in Brazil has undergone changes as leishmaniasis is no longer only considered a rural disease as there has been an expansion of the disease throughout Brazil with no signs that the spread is under control (2). There are more than 900 species of sand flies described in the world, 500 of which occur in the Neotropical region (3). Studies addressing the relationships among sand flies, protozoans, and hosts are of fundamental importance to control measures aimed at reducing the expansion of leishmaniasis (4).

Phlebotomine sand flies were only recently described in the city of Lavras in the southern portion of the state of Minas Gerais (southeastern Brazil) after an epidemiological canine serological survey was performed, in which the 579 of 6783 are infected with Leishmania sp. In 2017, the first case of human visceral leishmaniasis was detected in the area, which reflects the expansion of Leishmania transmission into the urban environment within the country.

Faced with this serious and still neglected public health problem, it is necessary to conduct studies that investigate not only human and canine cases, but also the sand fly fauna, since these insects constitute the vector that maintains the transmission cycle of Leishmania. Thus, the aim of the present study was to investigate the sand fly fauna in the municipality of Lavras in the state of Minas Gerais and its natural infection by Leishmania spp.

\section{Material and Methods}

\section{Study area}

This study was conducted in Lavras (Figure 1), a municipality in the state of Minas Gerais in southeastern Brazil $\left(21^{\circ} 14^{\prime} 43^{\prime \prime S} 44^{\circ} 59^{\prime} 59^{\prime \prime} \mathrm{W}\right)$ located $184 \mathrm{~km}$ from the

Correspondence: J.M.P. Barçante: <joziana@dsa.ufla.br> 
state capital Belo Horizonte. According to the Köppen classification, the climate of the city is Cwa: subtropical dry winter with temperatures below $18^{\circ} \mathrm{C}$ and hot summer with temperatures above $22^{\circ} \mathrm{C}(5)$.

\section{Collection and identification of sandflies}

Automatic HP light traps (HP Biomédica, Brazil) (6) were installed from February 2016 to February 2017 in the peridomicile area of residences located in areas with a high incidence of canine visceral leishmaniasis. Six traps were installed (one per residence) at 6:00 p.m. and removed at 6:00 a.m. over three consecutive days, resulting in a sampling effort of 216 total trap hours for this collection effort. Shannon traps were also deployed in semipreserved areas and HP light traps were installed in the peridomicile area of the residence at which the first human case of visceral leishmaniasis was reported in the area.

Male and female phlebotomine sand flies were identified using the classification proposed by Galati (7). Male sand flies were slide-mounted in Canada balsam. Female sand flies were dissected on a slide containing PBS and then placed in Berlese fluid overnight for clarification (8).

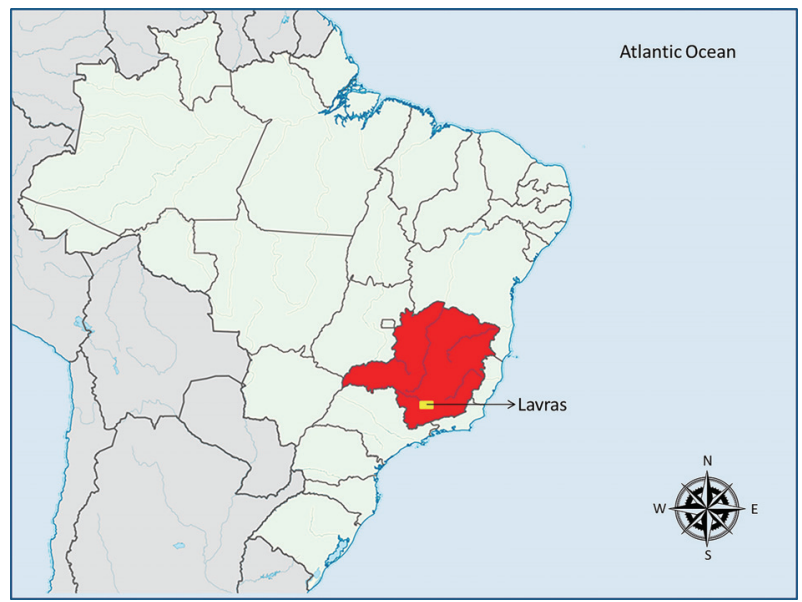

Figure 1. Location of the municipality of Lavras, Minas Gerais, Brazil.
All female insects were further identified focusing on the head to view the cibarium and the four final segments in the eighth tergite to view the spermatheca.

\section{DNA extraction from female sandflies and PCR} directed at internal transcribed spacer I (ITS I)

Deoxyribonucleic acid was extracted using the Gentra Puregene kit (Qiagen, USA) following previous protocol (9). The assessment of nucleic acid purity was assessed in a NanoDrop 2000/2000c Spectrophotometer (Thermo Fisher Scientific, USA) using the absorbance ratio of A260/280, and the DNA-concentration was evaluated in Qubit Fluorometric Quantitation (Thermo Fisher Scientific) using DNA Broad Range protocol as described by the manufacturer. PCR samples were heated at $37^{\circ} \mathrm{C}$ for $20 \mathrm{~min}$. Samples were prepared for a final volume of $25 \mu \mathrm{L}$ containing $5 \mu \mathrm{L}$ of the DNA sample to be tested, 1x buffer solution, $1.5 \mathrm{mM}$ of $\mathrm{MgCl}_{2}, 0.2 \mathrm{mM}$ of dNTP mix, and $0.5 \mu \mathrm{M}$ of each primer (LITSR: 5'CTGGATCATTTTCCGATG3' and L5.8S: 5'TGA TACCACTTATCGCACTT3') to amplify a fragment of 300 $\pm 350 \mathrm{bp}$ of the intergenic region of Leishmania DNA (internal transcribed spacer q-ITS1) (10). The thermocycling parameters were the same as described in a previous study (11). Amplifications were processed in an Eppendorf ${ }^{\mathbb{R}}$ Mastercycler Gradient automatic thermal cycler (Germany), subjected to electrophoresis in $1 \%$ agarose gel, and stained with ethidium bromide $(10 \mathrm{mg} / \mathrm{mL})$. In all reactions, reference strains of $L$. braziliensis (MHOM/BR/75/M2903) were used as positive controls.

\section{Results}

A total of 70 sand fly specimens were collected with the HP light traps in the peridomicile areas and 16 were collected with Shannon's traps in semi-preserved areas (Table 1). Only one of the specimens collected with Shannon's traps was identified (a Lutzomyia longipalpis male). Twenty-two female specimens were not identified due to loss of morphological structures.

From February 2016 to March 2016 (rainy season), HP light traps were installed weekly, resulting in a sampling

Table 1. Species of sand flies collected in Lavras, Minas Gerais, Brazil.

\begin{tabular}{lrcc}
\hline Species & Male & Female & Relative abundance \\
\hline Lutzomyia longipalpis & 22 & 21 & 0.67 \\
Migonemyia migonei & 2 & 8 & 0.15 \\
Evandromyia complex cortelezzii & 1 & 4 & 0.07 \\
Nyssomyia whitmani & 0 & 2 & 0.03 \\
Psathyromyia lutziana & 1 & 0 & 0.02 \\
Evandromyia lenti & 0 & 1 & 0.02 \\
Brumptomyia sp. & 0 & 1 & 0.02 \\
Pressatia $s p$. & 0 & 1 & 0.02 \\
Total & 26 & 38 & 1.00 \\
\hline
\end{tabular}


effort of $1728 \mathrm{~h}$. In all other months, HP light traps were installed only one week per month, resulting in a sampling effort to $216 \mathrm{~h}$ per month. The highest number of specimens was found in July (dry season). Shannon's traps were deployed in semi-preserved areas in September, October and December, with the highest number of specimens collected in September (14 sandflies).

The molecular analysis revealed that five (8.33\%) out of 60 females of flies captured were positive for Leishmania DNA. Positive females were all identified as Lutzomyia longipalpis.

\section{Discussion}

Several sand fly species have been implicated as Leishmania vectors and usually this association is made according to the dominant species in a given endemic area. Studies on the prevalence of Leishmania infection in sand flies are important indicators of the intensity of parasite transmission (12).

The kinetoplast is present in 10,000 copies per cell and its sequence is known in most species of Leishmania. Thus, we performed a PCR assay designed to amplify a fragment of $300 \pm 350 \mathrm{bp}$ of the intergenic region of Leishmania DNA (q-ITS1) due to their good applicability (10). The molecular methods, such as PCR-based techniques, have a high sensitivity and specificity, regardless of the number, stage, and location of the parasite in the insect gut, being an important tool in epidemiological studies to identify infected sand flies and to determine their infection rates in areas endemic for leishmaniasis (13).

With the exception of $L u$. longipalpis, which was the most abundant species, low relative abundance was found for most sand fly species in Lavras (Table 1). The number of species found corresponds to $7.21 \%$ of the 97 species of sandflies registered in the entire state of Minas Gerais (14).

\section{References}

1. Ross R. Further notes on Leishmania's bodies. BMJ 1903; 11: 1401, doi: 10.1136/bmj.2.2239.1401.

2. Werneck GL. Visceral leishmaniasis in Brazil: rationale and concerns related to reservoir control. Rev Saude Publica 2014; 48: 851-856, doi: 10.1590/S0034-8910.201404800 5615.

3. Shimabukuro PHF, Tolezano JE, Galati EAB. Chave de identificação ilustrada dos Phlebotominae (Diptera, Psychodidae) do estado de São Paulo, Brasil. Pap Avulsos de Zool 2011; 51: 399-441, doi: 10.1590/S0031-10492011002700001.

4. Almeida PS, Nascimento JC, Ferreira AD, Minzão LD, Portes F, Miranda AM, et al. Espécies de flebotomíneos (Diptera, Psychodidae) coletadas em ambiente urbano em municípios com transmissão de Leishmaniose Visceral do Estado de Mato Grosso do Sul, Brasil. Rev Bras Entomol 2010; 54: 304-310, doi: 10.1590/S0085-56262010000200014.

5. Dantas AAA, Carvalho LG, Ferreira E. Classificação e tendências climáticas em Lavras, MG. Ciênc Agrotec
Lutzomyia longipalpis is characterized by high adaptability to human environments (15). In Brazil, this is the most important vector involved in the transmission of Leishmania infantum, which is responsible for the viscerotropic form of leishmaniasis, a more severe clinical form of the disease $(16,17)$. Other species found also merit attention, such as Migonemyia migonei, which is described as a potential vector of Leishmania infantum, Leishmania mexicana, Leishmania guyanensis, and Leishmania panamensis; and Nyssomyia whitmani, which is a confirmed vector of Leishmania braziliensis, Leishmania guyanensis, and Leishmania shawi as well as a probable vector of Leishmania lainsoni (18).

In order to study the presence of Leishmania DNA in sand flies in the municipality of São João das Missões in northern Minas Gerais state, the presence of Leishmania DNA was detected in eleven samples from peridomicile areas, twelve samples from among the trails (19). In a study on the sand fly fauna in Belo Horizonte city, also in the state of Minas Gerais, a total of 579 phlebotomine sand flies were collected from which $68.7 \%$ were females and those specimens were used for natural infection examination by PCR. No Leishmania DNA was present in any of the specimens tested (20). The sand fly infection rate in the municipality of Janaúba was $3.9 \%$, according to Michalsky et al. (15). Expansion of the geographic distribution of leishmaniasis has been notified in nearly all states of Brazil, including Minas Gerais where it is endemic. There is considerable species diversity in the municipality studied, where human cases of visceral leishmaniasis are beginning to be reported.

\section{Acknowledgments}

We especially thank Beatriz Mendonça for help with the installation of traps.

2007; 31: 1862-1866, doi: 10.1590/S1413-7054200700060 0039.

6. Pugedo H, Barata RA, França-Silva JC, Silva JC, Dias ES. HP: um modelo aprimorado de armadilha luminosa de sucção para a captura de pequenos insetos. Rev Soc Bras Med Trop 2005; 38: 70-72, doi: 10.1590/S0037-8682200 5000100017.

7. Galati EAB. Classificação de Phlebotominae. In: Rangel EF, Lainson R (Editors), Flebotomíneos do Brasil Rio de Janeiro: Fiocruz; 2003. p 23-53.

8. Langeron M. Précis de microscopie. Saint-Germain: Masson et Cie. Libraires de L'Académie de Medicine; 1949.

9. Quaresma PF, Rêgo FD, Botelho HA, da Silva SR, MouraJunior AJ, Teixeira-Neto RG. Wild, synanthropic and domestic hosts of Leishmania in an endemic area of cutaneous leishmaniasis in Minas Gerais State, Brazil. Trans $R$ Soc Trop Med Hyg 2011; 105: 579-585, doi: 10.1016/j.trstmh.2011. 07.005 . 
10. el Tai NO, Osman OF, El Fari M, Presber W, Schönian G. Genetic heterogeneity of ribosomal internal transcribed spacer (ITS) in clinical samples of Leishmania donovani spotted on filter paper as revealed by single-strand conformation polymorphisms (SSCP) and sequencing. Trans $R$ Soc Trop Med Hyg 2000; 94: 575-579, doi: 10.1016/S00359203(00)90093-2.

11. Schonian G, Nasereddin A, Dinse N, Schweynoch C, Schallig HD, Presber $W$, et al. PCR diagnosis and characterization of Leishmania in local and imported clinical samples. Diagn Microbiol Infect Dis 2003; 47: 349-358, doi: 10.1016/S0732-8893(03)00093-2.

12. Rossi E, Bongiorno G, Ciolli E, di Muccio T, Scalone A, Gramiccia M, et al. Seasonal phenology, host-blood feeding preferences and natural Leishmania infection of Phlebotomus perniciosus (Diptera, Psychodidae) in a high endemic focus of canine leishmaniasis in Rome province, Italy. Acta Trop 2008; 105: 158-165, doi: 10.1016/j.actatropica.2007.10.005.

13. Aransay AM, Scoulica E, Tselentis Y. Detection and identification of Leishmania DNA within naturally infected sand flies by seminested PCR on minicircle kinetoplastic DNA. Appl Environ Microbiol 2000; 66: 1933-1938, doi: 10.1128/AEM.66.5.1933-1938.2000.

14. Andrade AJ, Dantas-Torres F. Phlebotomine sand flies (Diptera: Psychodidae) of the state of Minas Gerais, Brazil. Neotrop Entomol 2010; 39: 115-123, doi: 10.1590/S1519566X2010000100016.

15. Michalsky EM, Guedes KS, Silva FOL, França-Silva JC, Dias CLF, Barata RA, et al. [Infecção natural de Lutzomyia
(Lutzomyia) longipalpis (Diptera: Psychodidae) por Leishmania infantum chagasi em flebotomíneos capturados no município de Janaúba, Estado de Minas Gerais, Brasil] [in Portuguese]. Rev Soc Bras Med Trop 2004; 44: 58-62, doi: 10.1590/S0037-86822011000100014.

16. Gontijo CMF, Melo MN. Leishmaniose visceral no Brasil: quadro atual, desafios e perspectivas. Rev Bras Entomol 2004; 7: 338-349.

17. Lainson R, Rangel E. Lutzomyia longipalpis and the ecoepidemiology of American visceral leishmaniasis, with particular reference to Brazil: A Review. Mem Inst Oswaldo Cruz 2005; 100: 811-827, doi: 10.1590/S0074-027620050 00800001.

18. Akhoundi M, Kuhls $\mathrm{K}$, Cannet A, Votýpka J, Marty $\mathrm{P}$, Delaunay P. A Historical overview of the classification, evolution, and dispersion of leishmania parasites and sandflies. PLoS Negl Trop Dis 2016; 10: e0004349, doi: 10.1371/journal.pntd.0004349.

19. Rêgo FD, Rugani JMN, Shimabukuro PHF, Tonelli GB, Quaresma PF, Gontijo CMF. Molecular detection of Leishmania in phlebotomine sand flies (Diptera: Psychodidae) from a cutaneous leishmaniasis focus at Xakriabá Indigenous Reserve, Brazil. PLoS One 2015; 10: e0122038, doi: 10.1371/journal.pone.0122038.

20. Souza CMD, Pessanha JE, Barata RA, Monteiro ÉM, Costa DC, Dias ES. Study on phlebotomine sand fly (Diptera: Psychodidae) fauna in Belo Horizonte, state of Minas Gerais, Brazil. Mem Inst Oswaldo Cruz, 2004; 99: 795803, doi: 10.1590/S0074-02762004000800003. 